\title{
Student Activists or Student Anarchists? South Africa's Contemporary Student Protests Reviewed
}

\author{
Mashele RAPATSA \\ Faculty of Management and Law, University of Limpopo, South Africa. \\ LLB (UL) LLM (UCT), PhD candidate University of Groningen (Netherlands)
}

(C) 2017 Mashele Rapatsa

This is an open access article distributed under the Creative Commons Attribution-NonCommercial-NoDerivs license (http://creativecommons.org/licenses/by-nc-nd/3.0/)

DOI: 10.1515/eras-2017-0005

\begin{abstract}
Just over twenty-three years ago, the right to strike or protest received an explicit constitutional entrenchment and thus, legal protection. This would progressively empower citizens, including students, to protest against any infringement or deprivation of their rights or entitlements, and poor service delivery by any stakeholder in the institutions of learning, the government or private sector even. Today, South Africa is inundated with multiplicity of nationwide protests, most of which have been accompanied by appalling levels of violence, anarchy and criminality. Unexpectedly, students have had their share in such protests, and it could be argued, they have been an inspiration to various communities. Hence, this article proffers a critical reflection of the conduct of students during protests at the institutions of higher learning. The article seeks to understand and or explain variables that motivate students to vandalise property or antagonise those that opt to be passive or nonparticipants of such protests. In comparison to variables identified concerning the 1976 student protests, which were ideologically well grounded, the article attempts to describe contemporary students' thinking towards protests and why vandalism and anarchism have become, not only conventional, but so intensely socialised. The article adopts content analysis method, and employs crowd theory and collective behaviour approach as tools of analysis. It is asserted that lack of ideological strategy underpinning South Africa's unending revolution, which is needed to inform students' struggles, is responsible for pervasive tendencies of vandalism and destruction of property during student protests.
\end{abstract}

Keywords: Student Protests, Social Movements, Human Rights, Public Participation, Violence and Destruction of Property

\section{INTRODUCTION}

Historically, students have always played a significant role in shaping institutions of learning, especially those such as universities and technical colleges, and society's social settings in the end. Often students' involvement in such campus politics, which also drew inspiration from national politics, culminated in changes, either destructive or constructive, and such changes would define the future of higher education and societal prospects at large. Altbach (1989:97) states that although students' political activism has generally been oppositional in nature, there are instances where students have been involved in crucial developmental academic matters, and commendably played an influential role in driving anticolonial nationalist movements and fundamental reforms destined to be pro-poor and advance social justice in particular. Further that every nationalist and independence struggle had a strong component of student participation. Therefore, students and other youth are recognised to have been among social forces clamouring for political and economic changes (Nkinyangi, 1991:157). South Africa's exemplified experience of students' political activism was excellently epitomised in nine-teen seventy-six (1976), which is now popularly cited as the ' 1976 Soweto Uprisings'. The protests and demonstrations were of course characterised by the presence of a strong sense of nationalism among students. For instance, students, mainly 
from black schools, protested against the use of Afrikaans language as a medium of instruction. That incident contemporaneously defined the future of primary, secondary and higher education, and influenced changes in major socio-political discourses concerning education and the role of youth in regard to human and societal development.

Of course, it is worth mentioning that things have changed. This refers specifically to the political climate and dynamics defining collective struggles. In the past, student activists, who carried with them, deeply entrenched traits of nationalism were informed by a common struggle to fight against oppression, repressive legal systems, racial segregation and disenfranchisement. Whereas history informs that student protests were regularly accompanied by nationalism ideals, the contemporary South Africa suggests that racial essentialism has also entered the space (Habib, 2016), and this compounds the emotional outbursts ascribed to modern student protests. Thus, is there any connection between the supposed racial essentialism and historical disadvantage, present privilege by minority, and destruction of university property and violence on the part of students, which is often deducible when assessing the aftermath of such protests?

Today, struggles are more concerned with access to education, protection of human rights, human freedoms and social justice, in an egalitarian climate, under which public participation, including that of students, is one of the essential tenets upon which the primacy of effective governance is founded. Therefore, it is critical to recognise that in the contemporary world, conditions that surround students' efforts to participate in campus social and political activities in an effort to effect changes in the institutions of higher learning may provide educational and empowering citizenship experiences or may frustrate and further marginalise student citizens (Hamrick, 1998:449). It is for this reason that perhaps it would have been crucial for the post-apartheid dispensation to make adequate effort towards socialising students and preparing them for mature participation in processes that define the post liberation higher education.

\section{PROBLEM STATEMENT}

Socio-political protest action and social movements have been part of South Africa's social setting for many decades. Today, notions such as protest, strike, demonstrations and boycott have even become synonymous with the country itself. Historically, such protests always occurred within the context of desires for attainment of civil and political rights, such as freedom of association, dignity, equality, freedom of political expression, freedom of assembly (du Pisani et al, 1990). In contrast, a thorough reading of modern protests suggests that focus has been shifted to individual rights such as the rights to social security, access to basic commodities, dignity, equality and development, mainly because these aspects have perceivably become symbols of privilege and exclusivity for the political elite, their families and the Marx defined bourgeoisies in the private sector. Therefore, the contemporary student protests, which somewhat have also influenced societal service delivery protests, are not necessarily a new phenomenon.

During the 2015 and 2016 academic years, South Africa experienced spontaneous eruption of two intersected social movements. Such social movements attracted attention across all spectrums of society, including outside the country. Each of them ran with a distinct name, which became known as \#RhodesMustFall and \#FeesMustFall respectively, all of which were predominantly premised on discourses that linked historical disadvantage and privileges presently being enjoyed by minority in various sections of society. Unmistakably, issues raised during these social movements are genuine, and resolving them should never be 
deferred any further. If unresolved, the post-1994 promise story of ending racial divisions, economic exclusions and inequalities, and culmination of social harmony, communal development and collective prosperity as highlighted by Soudien (2007:182) will remain a hollow rhetoric. In the main, students have remonstrated about pervasive alienation of the previously disadvantaged groups, slow pace of transformation, inaccessibility of education and exclusivity of certain universities, all of which perpetuate apartheid's exclusive social and economic development in society, if left unaltered.

Whereas it is accepted that the two social movements presupposed that access to education has now permeated the space of student political consciousness, it is argued, within the same context, that these demonstrations epitomised a substantial amount of deep-seated anguish, an anger which accumulated over years, and is now precipitating partly because of both historical disadvantage, and presently diminishing socio-economic prospects. It is argued that these student's social movements ought to be re-strategized, perhaps in consultation with history, the 1976 part in particular, and its distinguishing feature of nationalism, as opposed to racial essentialism.

For the period 2016 academic year alone, the Minister of High Education and Training (DHET), Dr. Blade Nzimande, reported that the damage sustained by universities owing to torching and destruction of libraries, laboratories and lecture halls among others skyrocketed to over R600 million (approximately, \$42 million). How is this to be explained, especially within the context of 'fighting' for good quality education? Thus, is South Africa experiencing student activism or just another phase of student anarchism and or hooliganism? How would one justify the destruction of property and violence towards non-participating citizens, especially within the context of redressing the imbalances of the past, in an egalitarian setting? Further, how is the struggle against socio-economic exclusions advanced through destruction, violence and contemptuousness towards academic and administrative staff?

It should be understood that for decades, protests have been part and parcel of students' social and political lives within educational institutions, inclusive of secondary and tertiary institutions. This was particularly widespread under apartheid, but still remain ubiquitous twenty-three years after transition into the democratic dispensation. Such student protests have historically been associated with discontent resulting from poor services, racial repression, inequalities, and in the recent past, lack of transformation, high costs of education and inadequate provisioning of significant apparatus that define advancement and achievement of good quality education. It has been observed that since 2007, student protests have understandably become rampant, most of which have adopted 'militant' social movements approach, often characterised by appalling levels of destruction of the much needed public property and violations of fundamental human rights and freedoms of nonparticipating stakeholders. For the reasons that these student protests have problematically become so violent in nature (StatsSA, 2016), it is essential to begin to enter into a space of discussion building, in an effort towards distinguishing and isolating legitimate and useful student social movements from 'coloured revolutions', frequently lead by unconscious lumpen anarchists, often accompanied by manifest external influence, and who often cannot appreciate the effects of destruction of property and violations of human rights and freedoms at the institutions of higher learning. According to Koen et al (2006), student protests have been characterised by disruption of academic activities, aggressive behaviour towards university staff and students and large-scale vandalism of universities property.

The Statistician General, Dr Padi Lehohla, also reported that student protests have been escalating across all institutions of higher learning in South Africa. What is discernible from the above anecdote is the presence of solid consensus concerning modern student 
protests, that they have devastatingly become wild and regressive. And according to Mbeki and Mbeki (2016:102), the plights associated with protests entails that South Africa is going through a transition of a hidden civil war. Mbeki and Mbeki's assertion presupposes that the soaring violent service delivery protests should never be perceived as innocent ordinary protests. They symbolise a subconscious social problem just waiting to explode another day. This may be attributable to the fact that violence, either against human beings, animals or non-living objects has somewhat become peculiarly normalised. Instead of seeking to avert the situation, university students, who are supposed to be at their highest level of intelligence building, to suggest they would understand things better, seem to have joined the fray. Hence, this article reflects on student protests. While numerous surveys illustrate that there are grounds for linking modern social movements protests with the apartheid era (Alexander, 2010), it is difficult to fathom just how similar tactics are thought to still be relevant to the present day dispensation.

At the centre of attention in this article is not whether the issues that culminate in student protests are legitimate. The article is more concerned with the problem of violence and destruction of property. That is, how should it be explained within the context of social transformation, and the constitutional attempts of normalising society? Can the crowd theory and sociologists provide some sound explanations behind the establishment of violent student protests?

\section{RATIONALE, RESEARCH ISSUES AND METHODOLOGY}

First and foremost, this article resonates Popov and David's (2017:6) assertion that sociologists are better positioned, through their unique set of knowledge and expertise, to bring about positive social changes in society. That is, sociologists are a special breed of scholars, capable of explaining deep seated social challenges that shapes how people behave and interact with each other and social issues in society. But one wonders if sociologists would still be able to provide some explanations in relation to aspects that motivate students' behaviour and conduct which result in destruction of property during students' protests. The ultimate purpose of this article is to illustrate that South Africa's contemporary student activism is invariably disconnected from harsh realities of capitalism. Widespread experiences of students' protests have revealed a dismal failure to grasp the modern challenges and appreciate that the present government does not fully have nor own resources needed to wholly fulfil the political rhetoric and promises such as provisioning of free education, which the present dispensation ironically enshrined as constitutional entitlements. That student activists need to adapt and change their 'fighting' strategies, if ever they are engaged in a fighting process. The article argues that the strategies which were employed by students during the apartheid era would not be relevant or effective in the present egalitarian setting. In fact, a general observation is that distasteful destruction is always the end result, and often this exacerbates underdevelopment besieging the very previously disadvantaged students. The students need to be taught that apartheid was not defeated, but was negotiated, and this will for numerous decades, significantly determine the extent of the state's capacity to fulfil various constitutional promises.

Does violence produce student social movements' desired results? According to Altbach and Cohen (1990:34), violence which happens as a result of militant tactics and hyper-revolutionary rhetoric can have the effect of alienating a substantial portion of potential participants, and thus adversely affecting the legitimacy of student protests and prospects of future social activists' movements. This article uses content analysis method, and focused on secondary literature concerning the subject of student protests and social movements. The 
article also relied on informal responses obtained through semi-structured consultations with students, with the purpose of establishing students' understanding of modern day university protest, its primary purpose and outcome-based usefulness.

\section{THEORETICAL FRAMEWORK}

The objective of this article is to present variables that could constitute a framework which may be useful towards explaining the conduct, nature and form of contemporary student protests and demonstrations at the institutions of higher learning. I extrapolate one fundamental element located in the crowd theory to explain the basis of social movement support.

Most importantly, it is worth noting that social movements occur in a public domain, and thus often rely on an aspect of public support and sympathy. That is, student protests too somewhat do depend on public sympathy in order to overcome discontent and illegitimacy in the eyes of the public. But the most suited approach in the context of this article is the crowd theory and collective behaviour approach. This entails that participants ought to first understand the essence of protest, commit to it and consciously mobilise for its support. According to Hirsch (1990), it is appropriate to focus on how groups and the collective create commitment to their goals and tactics in protests. Most importantly, and for purposes of this article, the aspect of consciousness rising is most appealing. An ideal of raising consciousness is what informs the decision of potential participants on whether or not to join the protest. When a segment of society or institution(s) feels that they are alienated or disadvantaged in a certain way, and their concern will not be resolved either through strict political or legal processes, they create consensus through consciousness rising and thereafter decide the cause of action, which then informs their collective behaviour. This is particularly relevant in instances where motive forces of such movement protests stand to benefit from the provision of collective goods (Stern, 1999). So, this article uses the concept of consciousness rising to comparatively reflect on student protests of prior and post nineteen ninety-four, in an attempt to explain the extent to which ideological strategy assist in guiding collective commitment and behaviour.

\section{ACTIVISTS OR ANARCHISTS? A COMPARATIVE REFLECTION}

I venture to state that real activists are solid characters, individuals that are strongly informed by a combination of intuitive ideological approaches and who possess advanced levels of consciousness regarding material social, political and economic conditions afflicting society. On the other hand, anarchists are committed law and morality breakers, unscrupulous delinquents who characteristically subscribes to populism, pomposity and politics of rhetoric. So, how should the modern day student protests be understood within the context of distinguishing between activists and anarchists? Finding answers to this fundamental question depends on locating the discussion within a particular epistemology. That is, understanding the philosophy informing students' decision to embark on large-scale protests and vandalism.

South Africa's case can best be understood by making a comparative reflection of youth in times during or before 1976, and those after the post 1994 dispensation. This approach enables swift identification of epistemological factors that influenced the thinking of the 1976 student protests and those happening today. History reveals that student protests that took place in times towards 1976 were ideologically well-grounded. This entails that students who participated in such protests understood the need to suppress cultural imperialism and political indoctrination of the native masses. Therefore, the extent of consciousness raising 
was reasonably high. This can evidently be traced to the times of the formation and activism of the Black Consciousness Movement (BCM) and South African Students Organisation (SASO), whose leaders such as Professor Bantu Biko and Professor Barney Pityana mobilised students around ideologies premised on the rejection of subjugation by the racially repressive apartheid regime of minority, thereby elevating students level of political and social consciousness. Most importantly, the Black Consciousness Movement formulated and embraced an ideology that emphasised the importance of changing values, self-love, selfimage and psychology to undermine the idea of ascribed inferiority, with its fundamental goal being to achieve mental liberation in order to realize physical liberation (Howarth, 1994:23). Such ideologically grounded social movements culminated in students identifying areas of focus, and eventually enabled students to make distinctive contributions towards defining South Africa's future social and political climate (Franklin, 2003). In fact, students became a beacon of hope towards achieving a liberated nation.

There are specific aspects pointing how the 1976 student protests were informed by philosophical thoughts with clear epistemological location. These aspects informed students' decision whether or not to join and commit to such a social movement. First, students appreciated that their social backgrounds and sufferings largely emanated from deliberate human acts, which were enforced through subjugation and oppression processes of the natives. Second, that education was instrumental in empowering children and society, and therefore it had to be delivered in the language best understood by such learners. Third, an outright rejection of cultural imperialism and political indoctrination, which had long been earmarked for implementation through the classroom, church and lecture room by the coloniser. Fourth, that the then Bantu Education never intended to reinforce, awaken and develop the intellectual potential of the African student, and that the education system did not promote human values ascribable to egalitarian setting (Ndlovu, 2017. At the centre of their struggles were mainly, demands to abolish racial discrimination, social segregation, opposition to apartheid, (Morlan, 1970) and the creation of an environment under which all students are afforded equal opportunity to fully realise their potential and enhance both internal and external capabilities.

There is widespread anecdote that the contemporary student protests find added impetus and motivating force from actions of those students of the 1976 Soweto uprisings. But is it possible to locate an ideological relation between acts of the then youth and those of the present? The present article believes that there are specific variables defining these two eras, the 1960-1976 era and the 2006-2016 era in student socio-political protests. Variables that informed ideological struggle of the then youth were briefly outlined in the preceding paragraph. With regards to the 2006-2016 student protests, the author observes that while first, second and third generation rights and human entitlements remain pivotal factors; there are further social factors that have emerged. Firstly, the contemporary student protests are not necessarily premised on ideology. They mainly emanate from lack of fulfilment of the 1994 promises, which were even enshrined in the Constitution as rights. For instance, equality, dignity, social security, education, security of persons among others, got entrenched as rights, yet their realisation depends on financial abilities, thereby reinforcing societal exclusivity, even worse than under apartheid. Secondly, the proliferation of self-aggrandisement and egocentrism of political elite through practices such as VIPsm, which exacerbates the dissipation of hope that a better life for all will ever be realised (Rapatsa, 2016). It is asserted that this has created an unbearable social distance under which students feel isolated, while the political elite continue to enjoy opulence to the exclusion, and detriment of the poor. Thirdly, and most importantly, the fact that the previously privileged race groups still remain favoured by the present capitalistic material economic and political conditions, while the 
previously disadvantaged majority still remain the epitome of poverty and underdevelopment.

Therefore, the coining of 'rebellion of the poor' by Alexander (2010) is phenomenal. It talks indirectly to the issue that I want to advance. That, the modern day protests are not necessarily only based on discontent emanating from poor service delivery or lack of access to education and so forth. Instead, majority of poor people, the previously disadvantaged including students, are running out of patience owing to slow or lack of societal transformation, opulence being displayed through self-aggrandisement by the political elite, the elected representatives and lack of willingness by the previously privileged to abdicate the privilege and supremacy mentalities. Hence, the presumed absence of full social inclusion and social justice are the main drivers of despondency and the resort to anger discernible in student protests. And, when it erupts, it does so based on specific variables, while in actual fact it is fundamentally being driven by despondency. Sadly, violence renders modern students' protests fundamentally anarchic.

\section{CONCLUSION}

This article accentuates the view that active citizenry, especially amongst youthful members of society, students in particular, is an indispensable component that precedes successes of any egalitarian society. Thus, participation of youth in ideologically informed social, legal and political activities in the institutions of higher learning is a fundamental precursor of widespread societal literacy, social justice and sustainable social development. The article further indicates that the socio-political activism of the periods 1960-1976 played a significant role in shaping South Africa's socio-political trajectory until the country's transition to democracy. Students' thinking and the presence of strong ideological strategies sustained the 1976 students' struggles. Thus, students are reckoned in history to have ideologically fragmented apartheid and its executives.

In contrast, the contemporary students' approaches to protests represent a wholly new phenomenon, which is mired with aspects that not only discredit, but delegitimize authentic cries for meaningful transformation in higher education and society in general. This is simply because of pervasive violence and destruction of property which has become so badly socialised. Arguably, this is attributable to lack of clear ideological strategy, which also emanates predominantly from some of the post 1994 misconceptions such as 'apartheid was defeated', while the transition was a result of a negotiated settlement, accompanied by enormous compromises, that would deprive the state of the much needed economic capacities required to fulfil wider constitutional promises such as access to good quality higher education. Therefore, South Africa will, for some decades, continue to grapple with the effects of such political compromises and settlements which unfortunately did very little to alter the past, while enhancing state economic capacities to intervene and remedy inherited social inequalities. But given the supposed absence of this understanding among students, epistemologically speaking, there is high likelihood of violent student protests persisting. It is asserted that there is nothing wrong when students decide to embark on large-scale protests. However, there is everything wrong when such protests lack strategic ideological foundation, especially when protests culminate in destruction of the much needed property and costs to human health and or lives. Thus, there is very little evidence that could help dissociate the contemporary student protests from anarchy. 


\section{REFERENCES}

Alexander, P. (2010). Rebellion of the Poor: South Africa's service delivery protests - a preliminary analysis. Review of African Political Economy, 37(123), 25-40.

Altbach, P. G. (1989). Perspectives on Student Political Activism. Comparative Education, 25(1), 97-110.

Altbach, P. G. \& Cohen, R. (1990). American Student Activism: The Post-Sixties Transformation. The Journal of Higher Education, 61(1), 32-49.

Du Pisani, J. A., Broodryk, M. \& Coetzer, P. W. (1990). Protest Marches in South Africa. The Journal of Modern African Studies, 28(4), 573-602.

Franklin, V. P. (2003). Patterns of Student Activism at Historically Black Universities in the United States and South Africa, 1960-1977. The Journal of African American History, 88(2), 204-217.

Hamrick, F. A. (1998). Democratic Citizenship and Student Activism. Journal of College Student Development, 39(5), 449-459.

Hirsch, E. L. (1990). Sacrifice for the Cause: Group Processes, Recruitment, and Commitment in a Student Social Movement. 55(2), 243-254.

Howarth, D. (1994). The Ideologies and Strategies of Resistance in Post-Sharpeville South Africa: Thoughts on Anthony Marx's Lessons of Struggle. Africa Today, 41(1), 21-38.

Koen, C., Cele, M. \& Libhaber, A. (2006). Student activism and student exclusions in South Africa. International Journal of Educational Development, 26(), 404-414.

Mbeki, M. \& Mbeki, N. (2016). A Manifesto for Social Change - How to save South Africa? Johannesburg: Picador Africa.

Morlan, G. The Student Revolt against Racism in South Africa. Africa Today, 17(3), 12-20.

Ndlovu, S. M. (2017). The Soweto Uprisings - Counter-Memoirs of June 1976. Updated Edition with New Content. Johannesburg: Picador Africa.

Nkinyangi, J. A. (1991). Students protests in Sub-Saharan Africa. Higher Education, 22(2), 157-173.

Popov, P.L.\& David, G. (2017). Unveiling Hidden Social Design: New Roles for Sociologists. European Review of Applied Sociology, 10(4), 6-19.

Rapatsa, M. (2016). 'VIPsm', A Threat to Social Stability in South Africa: From Apartheid Exclusions to Democratized Inequalities. European Review of Applied Sociology, 9(13), 6-14.

Soudien, C. (2007). The "A" factor: Coming to terms with the question of legacy in South African education. International Journal of Educational Development, 27(2), 182-193.

Statistics South Africa (2016). Mbalo Brief - the missing piece of the puzzle. May 2016, Pretoria.

Stern, P. C., Dietz, T., Abel, T., Guagnano, A. G. \& Kalof, L. (1999). A Value-Belief-Norm Theory of Support for Social Movements: The Case of Environmentalism. Human Ecology Review, 6(2), 81-97. 